\title{
Strategi Pembelajaran Pendidikan Agama Kristen di Era Society 5.0
}

\author{
Learning Strategy for Christian Education in the Era of Society 5.0
}

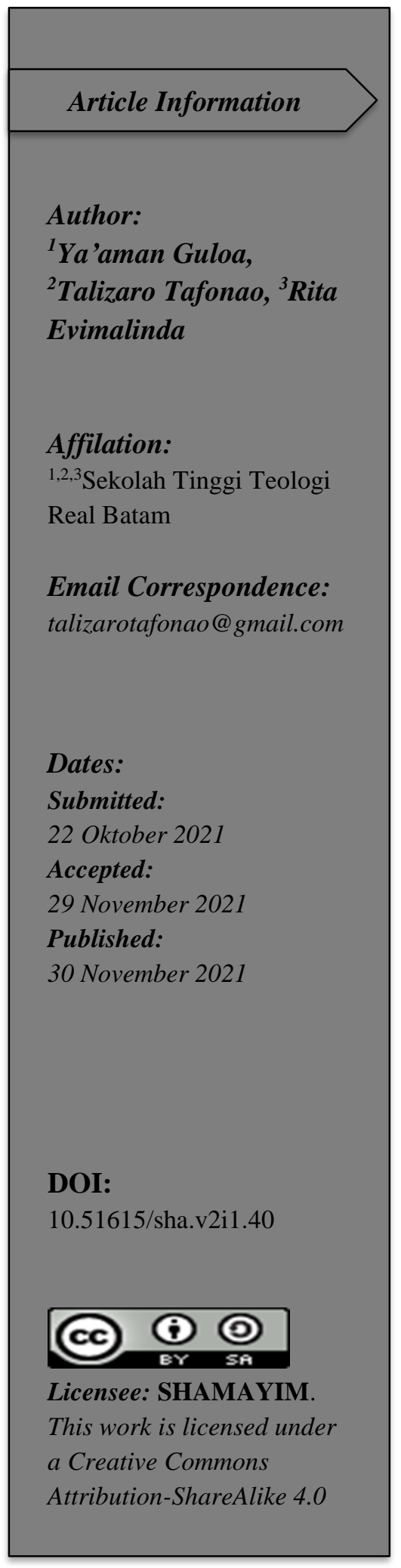

Abstract: The purpose of writing this article is to explain learning strategies that are relevant in the 5.0 era of society in learning Christian religious education. The author observes that the learning strategy is a means to achieve the learning objectives that have been set. Because one of the challenges faced by teachers today is the development of technology. The era of society 5.0 demands a teacher to be more creative, innovative and informative. That's why, the author reviews this paper to provide some tricks and tips so that teachers are able to compete and use appropriate learning strategies in the era of society 5.0. The method used in this study is a descriptive qualitative research method by examining the learning strategies of Christian religious education in the era of society 5.0. The method used in this study is a descriptive qualitative research method by examining the learning strategies of Christian religious education in the era of society 5.0. The results obtained in this study show that one of the learning strategies for Christian religious education in the era of society 5.0 that are still relevant are participatory strategies, inquiry strategies, discovery learning strategies, cooperative strategies, and blended learning strategies. Thus, the era of society 5.0 is a community concept that was developed to apply and balance the use of technology in everyday life so that access occurs in virtual space and physical space to solve social problems in order to create super smart humans.

Keywords: Learning Strategy, Christian Education, Society 5.0

Abstrak: Tujuan penulisan artikel ini adalah menjelaskan strategi pembelajaran yang relevan di era society 5.0 dalam pembelajaran Pendidikan Agama Kristen. Penulis mengamati bahwa strategi pembelajaran merupakan sarana untuk mencapai tujuan pembelajaran yang sudah ditetapkan. Karena salah satu tantangan yang dihadapi oleh guru saat ini adalah perkembangan teknologi. Era society 5.0 menuntut seorang guru untuk lebih kreatif, inovatif dan informatif. Oleh karena itu, penulis mengkaji tulisan ini untuk memberi beberapa trik dan tips agar guru-guru mampu bersaing dan menggunakan strategi pembelajaran yang tepat di era society 5.0. Metode yang digunakan dalam penelitian ini adalah metode penelitian kualitatif deskriptif dengan mengkaji strategi pembelajaran Pendidikan Agama Kristen di era society 5.0. Hasil yang dapatkan dalam kajian ini menunjukan bahwa salah satu strategi pembelajaran Pendidikan Agama Kristen di era society 5.0 yang masih relevan adalah strategi partisipatif, strategi inkuiri, strategi discovery learning, strategi koorperatif, dan strategi blended learning. Dengan demikian bahwa era society 5.0 adalah sebuah konsep masyarakat yang dikembangkan untuk mengaplikasikan dan menyeimbangkan penggunaan teknologi dalam kehidupan sehari-hari sehingga terjadinya akses dalam ruang virtual dan ruang fisik untuk memecahkan masalah sosial agar terciptanya manusia yang super smart.

Kata Kunci: Strategi Pembelajaran, Pendidikan Agama Kristen, Society 5.0 


\section{Pendahuluan}

Dunia pendidikan sedang memasuki era baru, yaitu era society 5.0. Era society 5.0 membawa perubahan yang signifikan dalam pendidikan, khususnya Pendidikan Agama Kristen. Pendidikan Agama Kristen bertujuan untuk mengajar peserta didik memahami Alkitab dengan cerdas sebagai sumber pembelajaran.(Ipiana et al., 2021)

Dengan adanya perkembangan teknologi yang semakin maju, mengharuskan guru Pendidikan Agama Kristen memiliki keterampilan dalam memanfaatkan teknologi untuk mencegah dampak negatif teknologi dalam proses pembelajaran. Pembelajaran Pendidikan Agama Kristen membutuhkan strategi yang tepat dalam menghadapi era society 5.0 agar peserta didik mampu mengikuti perkembangan zaman dengan baik dan bersaing sehat dikancah nasional maupun internasional.

Strategi pembelajaran adalah sebuah kegiatan yang di dalamnya mencakup penggunaan metode dan sumber daya yang ada dengan maksimal untuk mencapai tujuan pembelajaran.(H. Mulyono \& Wekke, 2018) Sedangkan menurut Nasution strategi pembelajaran adalah pola pembelajaran yang digunakan oleh guru secara kontekstual sesuai dengan kebutuhan peserta didik, lingkungan sekolah dan tujuan pembelajaran yang sudah dirumuskan.(Nasution, 2017) Dengan demikian strategi pembelajaran adalah upaya guru dalam menggunakan sumber daya yang ada secara kontekstual dalam proses pembelajaran untuk mencapai tujuan pembelajaran.

Era society 5.0 merupakan sebuah inovasi yang dikembangkan untuk memberikan solusi atas masalah yang terjadi di era industri 4.0. Handayani dan Muliastrini, berpendapat bahwa kajian terhadap perkembangan industri 4.0 berpontensi mendegradasi peran manusia(Handayani \& Muliastrini, 2020). Selain itu, Diana juga mengungkapkan bahwa perkembangan industri 4.0 menyebakan kurangnya interaksi sosial antar individu.(Diana, 2019) Pendapat yang sama juga diungkapkan oleh Sururuddin, dkk mengatakan bahwa era 4.0 menggeser peran manusia oleh karena teknologi yang berdampak pada cara bersosialisasi dan bekerja(Sururuddin \& Dkk, 2021). Hal ini bisa saja terjadi dalam proses pembelajaran Pendidikan Agama Kristen dimana siswa bersikap tertutup dan individual sehingga pembelajaran akan menjadi kaku. Untuk mengatasi masalah tersebut, guru Pendidikan Agama Kristen membutuhkan strategi pembelajaran yang tepat, supaya proses pembelajaran di dalam kelas lebih interaktif.

Era society 5.0 hadir sebagai solusi atas kesenjangan yang terjadi pada era industri 4.0, dimana society 5.0 bertujuan untuk menyeimbangkan kemajuan teknologi dan menyelesaikan masalah sosial dengan mengintegrasikan ruang virtual dan ruang fisik (Handayani \& Muliastrini, 2020). Society 5.0 adalah sebuah konsep masyarakat yang berpusat pada manusia yang berbasis teknologi.(Nastiti \& 'Abdu, 2020) Setiawan dan Lenawati mengungkapkan bahwa era society 5.0 adalah sebuah konsep yang dikembangkan untuk membentuk masyarakat super smart yang dapat mengoptimalkan manfaat internet of things, big data, dan artificial intellegence sebagai solusi untuk kehidupan masyarakat yang lebih baik.(D. Setiawan \& Lenawati, 2020) Dengan demikian jelas bahwa era society 5.0 lebih dipusatkan pada keseimbangan antara penggunaan teknologi dengan peran dan interaksi sosial antar individu.

Perkembangan teknologi yang begitu cepat menuntut seorang guru untuk lebih kreatif dalam menggunakan teknologi. Kreativitas seorang guru sangat dibutuhkan dalam menggunakan teknologi, agar fungsinya dapat dioptimalkan dengan baik.(Ariefin \& Darmawan, 2021) Sururudin, dkk mengatakan bahwa tantangan guru di era society 5.0 adalah mempersiapkan strategi-strategi pembelajaran dalam membuat inovasi baru dengan menggunakan media teknologi(Sururuddin \& Dkk, 2021). Hal ini juga didukung oleh pendapat Handayani dan Muliastrini, mengatakan bahwa pendidikan saat ini sudah masuk dalam era society 
5.0, dimana era tersebut menuntut keseimbangan masyarakat, dimana teknologi tidak hanya sebatas informasi tetapi juga untuk menjalankan kehidupan.Handayani and Muliastrini, "Pembelajaran Era Disruptif Menuju Era Society 5.0 (Telaah Perspektif Pendidikan Dasar).” Berdasarkan pandangan tersebut, penulis melihat bahwa begitu pentingnya guru membuat inovasi dan strategi pembelajaran supaya proses pembelajaran terdapat keseimbangan antara perkembangan teknologi dengan peran guru dan peserta didik.

Ada beberapa penelitian sebelumnya yang sudah mengkaji tentang Strategi Pembelajaran Pendidikan Agama Kristen Di Era Society 5.0. Salah satunya adalah jurnal yang ditulis oleh Sururuddin, dkk, tahun 2021 yang mengkaji tentang strategi pendidik dengan media pembelajaran berbasis multimedia untuk menghadapi era society 5.0. Penelitian yang juga mengkaji strategi pembelajaran di era society 5.0 adalah jurnal yang ditulis oleh Ni Puti Sri Pinatih yang menjelaskan tentang pembelajaran yang menyenangkan dalam menyongsong era society 5.0, tahun 2020. Kedua penelitian tersebut sama-sama menjelaskan tentang strategi pembelajaran di era society 5.0, namun lebih menekankan pada strategi untuk mengembangkan dan mempersiapkan guru menghadapi era society 5.0, sedangkan jenis-jenis strategi pembelajaran yang harus diterapkan dalam kegiatan pembelajaran tidak dijelaskan dalam kedua penelitian tersebut. Oleh karena itu, tulisan ini bertujuan untuk menjelaskan strategi pembelajaran yang relevan di era society 5.0, khususnya dalam proses pembelajaran Pendidikan Agama Kristen.

\section{Metode Penelitian}

Metode yang digunakan untuk mengkaji tulisan ini adalah metode deskriptif kualitatif dengan pendekatan kajian pustaka. Metode kualitatif lebih fokus terhadap penyelidikan kebenaran yang relatif dengan menggunakan analisis teori untuk menarik kesimpulan.(Zaluchu, 2020) Kajian pustaka adalah mengumpulkan teori dan informasi dari kepustakaan yang berkaitan dengan topik penelitian sebagai landasan dalam pemecahan masalah penelitian.(Zaluchu, 2021). Albi dan Johan menambahkan bahwa penelitian kualitatif tidak menggunakan statistik, tetapi melalui pengumpulan data, analisis, kemudian diinterpretasikan (Setiawan, 2018). Kajian ini bertujuan untuk menjelaskan strategi pembelajaran yang relevan di era society 5.0. Setelah itu, peneliti memperoleh data melalui studi pustaka dan menelusuri karya ilmiah para peneliti sebelumnya yang telah dipublikasikan terkait tema kajian. Dengan menggunakan kepustakaan, peneliti mengumpulkan data melalui kajian terhadap artikel jurnal, buku-buku dan karya ilmiah yang dapat dipercaya. Kemudian peneliti menganalisis teori dan mendeskripsikan melalui teknik analisis data dengan beberapa tahapan, yakni mereduksi data, mengklasifikasi dan memferivikasi data untuk menarik kesimpulan.

\section{Hasil dan Pembahasan}

\section{Strategi Pembelajaran Pendidikan Agama Kristen, dan Society 5.0}

Dalam kegiatan belajar dan mengajar, seorang guru perlu menentukan sebuah strategi pembelajaran yang dapat membantu peserta didik memahami materi yang diajarkan. Secara etimologi strategi berasal dari bahasa Latin, yaitu Strategia, yang artinya adalah kemampuan dalam menyusun dan menggunakan sebuah rencana untuk mencapai tujuan (Nasution, 2017). Secara umum strategi dapat diartikan sebagai sebuah garis haluan dalam bertindak untuk mencapai sasaran dan tujuan tertentu (Asrori, 2013). Dengan demikian strategi sangat erat hubungannya dengan perencanaan dan pencapaian tujuan.

Menurut Mulyono dan Ismail strategi pembelajaran adalah sebuah rangkaian kegiatan termasuk di dalamnya penggunaan metode dan pemanfaatan berbagai sumber daya atau kekuatan dalam proses pembelajaran untuk mencapai tujuan pembelajaran (Mulyono \& Wekke, 2018). Keles mengutip pendapat 
yang mengatakan bahwa strategi pembelajaran merupakan cara yang dipilih oleh guru untuk menyampaikan materi dilingkungan pembelajaran yang meliputi sifat, lingkup dan urutan kegiatan yang dapat memberikan pengalaman belajar kepada peserta didik (Keles, 2020). Sedangkan menurut Wahyudin strategi pembelajaran adalah pola kegiatan pembelajaran yang dipilih oleh guru secara kontekstual sesuai dengan kebutuhan peserta didik, lingkungan sekolah, dan tujuan pembelajaran yang telah dirumuskan. Lebih lanjut dikatakan bahwa strategi pembelajaran terdiri dari metode, teknik, dan prosedur yang akan membawa peserta didik untuk benar-benar mencapai tujuan pembelajaran (Nasution, 2017). Pendapat yang sama juga diungkapkan Nana Sudjana yang dikutip oleh Asrori mengatakan bahwa strategi pembelajaran adalah tindakan mempengaruhi peserta didik untuk mencapai tujuan pembelajaran dengan lebih efektif dan efisien (Asrori, 2013). Oleh karena itu, dari beberapa pendapat di atas dapat disimpulkan bahwa strategi pembelajaran merupakan sebuah usaha terencana oleh guru dalam menggunakan dan memanfaatkan seluruh sumber daya yang ada untuk mencapai tujuan pembelajaran dengan lebih efektif dan efisien sehingga memberikan pengalaman belajar yang baik bagi peserta didik.

Sedangkan Pendidikan Agama Kristen adalah pendidikan yang bertujuan untuk membentuk karakter peserta didik sama seperti karakter Tuhan Yesus. Menurut Sinta Pendidikan Agama Kristen adalah salah satu cara untuk membawa seseorang dari perilaku yang buruk kepada perilaku yang baik melalui pengajaran Alkitab sehingga menjadi lebih dewasa dan bertanggungjawab dalam kehidupan sehari-hari (Simamora, 2019). Pendapat ini juga didukung oleh pernyataan Ipiana yang mengatakan bahwa Pendidikan Agama Kristen adalah pendidikan yang bertujuan untuk membimbing peserta didik dalam memahami Alkitab dengan cerdas agar dapat memasuki persekutuan hidup dengan Tuhan, berpusat pada Kristus dan bergantung pada Roh Kudus sepenuhnya sehingga peserta didik bertumbuh dalam karakter Kristus (Ipiana et al., 2021). Dengan demikian Pendidikan Agama Kristen adalah pendidikan yang bersumber pada Alkitab dan bergantung pada kuasa Roh Kudus untuk memperlengkapi peserta didik menjadi dewasa dan bertanggungjawab serta memiliki karakter yang baik. Artinya adalah Alkitab yang merupakan sumber pembelajaran Pendidikan Agama Kristen mengharuskan seorang guru dan peserta didik untuk benar-benar memahami firman Tuhan yang terkandung didalamnya sehingga bisa dilihat dengan utuh dan konkrit. Maka dari uraian di atas dapat ditarik kesimpulan bahwa strategi pembelajaran Pendidikan Agama Kristen adalah sebuah proses kegiatan pembelajaran yang dilakukan oleh guru dalam memanfaatkan metode dan sumber daya yang ada untuk membawa peserta didik lebih mudah memahami pembelajaran Alkitab sehingga peserta didik mengalami perubahan perilaku ke arah yang lebih baik dan bertanggungjawab.

Setelah memahami pengertian strategi pembelajaran di atas, maka perlu mengetahui fungsi strategi pembelajaran. Menurut Mulyono dan Ismail dalam buku yang berjudul strategi pembelajaran di abad digital menerangkan beberapa fungsi strategi pembelajaran (Mulyono \& Wekke, 2018), namun penulis merangkumnya sebagai berikut : fungsi strategi pembelajaran adalah 1) Untuk memilih dan menetapkan metode yang digunakan dalam menyampaikan materi pembelajaran sehingga lebih efisien dan efektif. 2) Untuk menarik perhatian peserta didik. 3) Untuk memberikan rangsangan atau stimulus kepada peserta didik supaya peserta didik lebih aktif dalam kegiatan pembelajaran. 3) Untuk mempermudah peserta didik dalam memahami materi yang disampaikan. 4) Untuk menciptakan suasana belajar yang kondusif dan menyenangkan. 5) Memudahkan peserta didik dan guru dalam berkomunikasi serta bersosialisasi. Berdasarkan fungsi di atas dapat ditemukan bahwa strategi pembelajaran sangat penting dan berpengaruh dalam proses pembelajaran, karena strategi pembelajaran memberikan kemudahan bagi siswa dalam memahami materi ajar serta memberikan suasana belajar yang tertib dan kondusif. 
Namun dalam penerapannya, alangkah baiknya jika strategi pembelajaran dikombinasikan dengan penggunaan media teknologi yang ada. Sudah tidak diragukan lagi bahwa perkembangan teknologi sangat berpengaruh bagi kelangsungan aktivitas manusia, termasuk aktivitas dalam dunia pendidikan. Tidak lama Indonesia memasuki revolusi industri 4.0 namun di tahun 2019 sudah diperkenalkan revolusi industri 5.0 atau dikenal dengan istilah society 5.0 oleh Jepang (Puspita et al., 2020). Siap tidak siap dunia pendidikan harus berusaha untuk mengikuti perkembangan tersebut. Jika tidak, mutu pendidikan Indonesia akan semakin ketinggalan.

Society 5.0 tidak jauh berbeda dengan revolusi industri 4.0. Jika industri 4.0 mengembangkan akses untuk mencari dan membagikan informasi di internet, maka society 5.0 menerapkan dimana teknologi adalah bagian dari manusia itu sendiri. Yang artinya adalah internet tidak hanya memberikan informasi tetapi juga menjalankan kehidupan (Puspita et al., 2020). Hal ini memungkinkan adanya peran dan sosialisasi antara individu dengan individu lainnya sehingga tidak hanya sekedar berkomunikasi di dunia virtual tetapi juga dalam dunia fisik (nyata).

Secara sederhana Faulinda dan Aghni mengatakan bahwa society 5.0 adalah sebuah konsep masyarakat yang berpusat pada manusia namun berbasis teknologi. Bahkan lebih ditekankan bahwa di era society 5.0 masyarakat dihadapkan dengan teknologi yang memungkinkan terjadinya akses dalam ruang maya terasa seperti ruang fisik (Nastiti \& 'Abdu, 2020). Berdasarkan pandangan ini jelas bahwa society 5.0 lebih dipusatkan pada keseimbangan penggunaan teknologi dengan peran dan sosialisasi antara manusia.

Menurut kabinet Jepang, seperti dikutip oleh Puspita, dkk mengatakan bahwa society 5.0 adalah sebuah masyarakat yang berpusat pada manusia yang menyeimbangkan kemajuan ekonomi dengan penyelesaian masalah sosial melalui sistem yang mengaplikasikan ruang virtual dengan ruang fisik (Puspita et al., 2020). Ide society 5.0 ini muncul akibat masalah yang terjadi di era revolusi 4.0 yang dinilai bahwa teknologi akan menggantikan peran manusia karena hanya bertukar informasi dan bersosialisasi melalui virtual saja. Pendapat ini didukung oleh Yenni Puspita, dkk yang mengatakan bahwa society 5.0 adalah sebuah masyarakat yang dapat menyelesaikan berbagai tantangan dan permasalahan sosial dengan memanfaatkan teknologi yang sudah ada di era industri 4.0 (Puspita et al., 2020).

Sedangkan menurut Dimas Setiawan dan Mei Leniwati era society 5.0 adalah sebuah konsep yang dikembangkan demi terbentuknya masyarakat super smart yang memiliki pola perilaku mengoptimalkan pemanfaatan internet of things, big data, dan artificial intellegence sebagai solusi untuk kehidupan masyarakat yang lebih baik (D. Setiawan \& Lenawati, 2020).

Oleh karena itu, dari beberapa pandangan di atas dapat disimpulkan bahwa society 5.0 adalah sebuah konsep masyarakat yang dikembangkan untuk mengaplikasikan dan menyeimbangkan penggunaan teknologi dalam kehidupan sehari-hari sehingga terjadinya akses dalam ruang virtual dan ruang fisik untuk memecahkan masalah sosial agar terciptanya manusia yang super smart demi kelangsungan hidup masyarakat yang lebih baik.

\section{Kontribusi Society 5.0 bagi Pendidikan Agama Kristen}

Kehadiran teknologi di era society 5.0 membawa perubahan yang signifikan dalam dunia pendidikan, termasuk Pendidikan Agama Kristen. Era society 5.0 ini harus dimanfaatkan oleh guru Pendidikan Agama Kristen dalam menyelaraskan pendidikan berbasis teknologi ke dalam kehidupan peserta didik, sehingga terciptanya keseimbangan antara penggunaan media teknologi (virtual) dengan dunia nyata.

Kurniawan dan Aiman mengatakan bahwa situasi yang sedang terjadi di era society 5.0 dapat dirasakan adanya perubahan fungsi sosial menuju fungsi teknologi informasi dalam setiap aktivitas 
kehidupan, termasuk dunia pendidikan. Lebih lanjut dikatakan bahwa pendidikan menjadi salah satu fungsi sosial yang berjalan seiring dengan peradaban termasuk peradaban society 5.0.(Kurniawan \& Aiman, 2020). Pandangan ini jelas bahwa pendidikan, lebih khusus Pendidikan Agama Kristen harus bisa menjalankan fungsi sosialnya dalam kehidupan peserta didik dan masyarakat yang berbasis teknologi, untuk menciptakan kemajuan bagi bangsa dan negara.

Sedangkan menurut Arjuanita mengatakan bahwa society 5.0 memberikan pengaruh dimana pendidikan 5.0 manusia dan teknologi diselaraskan untuk memperoleh solusi, memecahkan berbagai masalah yang dihadapi, serta menemukan berbagai inovasi baru yang dimanfaatkan dalam kehidupan manusia, termasuk dalam proses pembelajaran(Arjunaita, 2020). Pandangan ini jelas bahwa guru dalam proses pembelajaran harus mampu berinovasi dalam memanfaatkan media teknologi, termasuk dalam menentukan strategi pembelajaran yang sesuai dengan konteks kemajuan zaman, sehingga peserta didik memiliki pengalaman belajar yang menyenangkan.

Menurut Dunwill seperti dikutip oleh Arjunaita, mengatakan bahwa ada banyak perubahan di era society 5.0 dalam dunia pendidikan, yaitu a) perubahan khususnya dalam tata ruang kelas, b) virtual dan augmented reality akan mengubah sistem pendidikan, c) tugas yang fleksibel yang mengakomodasi berbagai gaya dan strategi dalam proses pembelajaran(Arjunaita, 2020). Tentu perubahan tersebut membutuhkan respon guru untuk mengembangkan dan memanfaatkannya dengan baik supaya perubahan tersebut membawa kemajuan bagi pendidikan di Indonesia.

Oleh karena itu, menurut pendapat penulis, kontribusi society 5.0 bagi pendidikan, khususnya bagi Pendidikan Agama Kristen adalah pertama memberikan stimulus kepada guru untuk mengembangkan kompetensinya dalam penguasaan teknologi, berinovasi, berpikir kritis, komunikasi dan koordinasi, serta menciptakan kreativitas dalam proses pembelajaran. Kedua, memotivasi guru untuk lebih menguasai literasi digital, baik itu literasi informasi, literasi media, maupun literasi moral. Ketiga, membantu guru dalam menjalankan tugas dan tanggungjawabnya, menjalankan interaksi sosial, beradaptasi dan memiliki jiwa kepemimpinan yang baik.

\section{Strategi Pembelajaran Pendidikan Agama Kristen di Era Society 5.0}

Strategi Partisipatif

Strategi pembelajaran partisipatif merupakan salah satu strategi pembelajaran yang relevan untuk diterapkan di era society 5.0. Strategi pembelajaran partisipatif adalah strategi pembelajaran yang melibatkan peserta didik dengan aktif dalam proses pembelajaran, mulai dari perencanaan, pelaksanaan, dan evaluasi (Mulyono \& Wekke, 2018). Sedangkan indikator keberhasilan strategi partisipatif seperti yang diungkapkan oleh Mulyono dan Wekke adalah 1) adanya keterlibatan emosional dan mental peserta didik dalam proses pembelajaran. 2) adanya kesediaan peserta didik dalam memberikan kontribusi untuk mencapai tujuan pembelajaran. 3) adanya keuntungan yang didapatkan oleh peserta didik selama kegiatan pembelajaran (Mulyono \& Wekke, 2018).

Strategi pembelajaran partisipatif juga relevan diterapkan dalam pembelajaran Pendidikan Agama Kristen dimana siswa dilibatkan lebih aktif dalam kegiatan pembelajaran. Dalam Alkitab dapat ditemukan contoh strategi partisipatif bahwa ketika Yesus memberikan pengajaran dalam sebuah perumpamaan, murid-murid-Nya bertanya kembali kepada Yesus tentang arti dari perumpamaan tersebut (Luk. 8:9) dan juga pada saat Yesus bertanya kepada murid-murid-Nya tentang siapa Dia, murid-murid-Nya memberikan jawaban atas pertanyaan tersebut (Mark. 8:27-29). Dari contoh tersebut dapat dikatakan bahwa dalam 
pembelajaran Pendidikan Agama Kristen dibutuhkan partisipasi aktif dari peserta didik untuk memahami topik pembelajaran dengan baik.

Dalam pembelajaran Pendidikan Agama Kristen dibutuhkan peran aktif dari peserta didik agar pembelajaran dapat berlangsung dengan baik dan mencapai tujuan pembelajaran dengan maksimal. Berdasarkan ciri strategi partisipatif, peserta didik adalah pelaku pembelajaran itu sendiri sedangkan guru berfungsi sebagai fasilitator dan motivator bagi peserta didik.(Muslim, 2017) Seorang guru Pendidikan Agama Kristen harus mampu memfasilitasi peserta didik agar aktif dalam pembelajaran. Peran aktif peserta didik yang diharapkan adalah aktif dalam bertanya dan aktif menyampaikan pendapat atau ide dalam pembelajaran.

Pendidikan Agama Kristen merupakan pembelajaran yang bersifat abstrak, seperti mengenal tentang siapa itu Yesus, tentang kasih, pengampunan, keselamatan dan sebagainya. Maka untuk menghasilkan ide, pendapat dan sikap kristis terhadap hal tersebut adalah dengan memanfaatkan media teknologi. Untuk memahami makna keselamatan dalam iman Kristen perlu literatur pendukung selain Alkitab sebagai sumber Utama. Di sini media teknologi dapat dikombinasikan dalam proses pembelajaran, misalnya dengan mencari sumber lain di internet. Namun, guru sebagai fasilitator mengarahkan peserta didik agar informasi yang ditemukan di internet tidak diterima begitu saja, tetapi perlu dikritisi oleh siswa, sehingga dalam proses pembelajaran terjadi interaksi sosial antar siswa dan guru, tidak selalu mengandalkan teknologi tetapi juga sikap kritis peserta didik dapat terlatih dan guru tetap berperan di dalam pembelajaran sebagai fasilitator dan motivator.

Dengan demikian bisa dikatakan bahwa strategi ini dapat diterapkan di era society 5.0, dimana strategi ini lebih mengutamakan keaktifan peserta didik dalam proses pembelajaran, mengajak peserta didik untuk berpikir kritis, kreatif, bebas, dan bertanggungjawab dalam kegiatan pembelajaran, serta memberdayakan peran peserta didik untuk bersosialisasi dan bekerjasama dalam memecahkan masalah yang dihadapi dengan memanfaatkan bantuan teknologi.

\section{Strategi Inkuiri}

Strategi inkuiri merupakan salah satu solusi untuk mengasah kemampuan berpikir peserta didik di era society 5.0. dimana strategi ini lebih menekankan pada kemampuan berpikir kritis. Strategi inkuiri adalah rangkaian proses pembelajaran yang menekankan pada proses berpikir kritis dan analisis untuk mencari dan menemukan sendiri jawaban dari suatu masalah yang dibahas dalam proses pembelajaran (Mulyono \& Wekke, 2018). Sedangkan menurut Royani menjelaskan bahwa strategi inkuiri merupakan rangkaian proses pembelajaran yang melibatkan secara maksimal seluruh kemampuan siswa untuk mencari dan menyelidiki secara sistematis, logis, dan analitis, sehingga peserta didik dapat merumuskan sendiri penemuan - penemuan tersebut dengan rasa percaya diri(Royani, 2020). Dengan demikian dapat dikatakan bahwa strategi inkuiri lebih menekankan pada keaktifan siswa dalam mencari, menganalisis dan menemukan solusi dari masalah atau topik yang dibicaran dalam proses pembelajaran.

Strategi inkuiri dapat ditemukan contohnya dalam Alkitab. Salah satunya adalah ketika Yesus menekankan kepada murid-murid-Nya agar waspada terhadap pengajaran orang farisi (Mar. 8:14-21). Dalam teks tersebut Yesus menyampaikan beberapa pertanyaan kepada murid-murid-Nya yang bertujuan untuk menstimulus agar mereka berpikir, menganalisis serta mencari kebenaran dibalik pertanyaan tersebut. Demikian juga dalam pembelajaran Pendidikan Agama Kristen. Guru Pendidikan Agama Kristen harus mampu memotivasi peserta didik untuk berpikir kreatif, analisis, serta memberikan solusi terhadap setiap permasalahan yang dibahas dalam pembelajaran yang sesuai dengan kebenaran firman Tuhan. 
Dalam pembelajaran Pendidikan Agama Kristen strategi inkuiri masih sangat relevan digunakan dalam pembelajaran Pendidikan Agama Kristen di era society 5.0. Strategi tersebut merupakan alat atau media untuk mengajar peserta didik menemukan kebenaran Alkitab serta menjawab pertanyaan tentang kekristenan secara tegas dan benar.(Dwijora \& Simanjuntak, 2020) Karena dalam mempelajari Alkitab selain membutuhkan iman juga membutuhkan analisis yang kuat untuk memahami arti yang sesungguhnya. Tentu dalam mencari jawaban atas pertanyaan tersebut dapat menggunakan media teknologi untuk mendapatkan informasi yang bisa membantu peserta didik menganalisis serta merumuskan jawaban yang tepat terhadap permasalahan yang sedang dipelajari.

Namun seorang guru juga harus memperhatikan ciri dan prinsip utama strategi inkuiri agar bisa dilaksanakan dengan baik. Salah satu ciri strategi pembelajaran inkuiri adalah lebih menekankan pada keaktifan peserta didik dengan maksimal untuk mencari dan menyelidiki, artinya peserta didik adalah subjek atau pelaku utama dalam kegiatan pembelajaran.(H. Mulyono \& Wekke, 2018) Peserta didik tidak hanya menerima materi dari guru, tetapi peserta didik juga diajak untuk berpikir kritis sehingga bisa menemukan inti dari pembelajaran tersebut. Tentu peran guru sebagai pembimbing dan fasilitator sangat dibutuhkan, agar proses pembelajaran dapat terarah dan pada akhirnya tetap terjalin interaksi sosial yang baik dalam pembelajaran.

Oleh karena itu, strategi inkuiri merupakan strategi yang efektif untuk diterapkan di era society 5.0 dimana strategi ini lebih menekankan peserta didik untuk aktif menemukan solusi dan inti dari setiap topik pembelajaran yang dibicarakan. Selain itu, strategi ini juga melatih peserta didik untuk mengembangkan dirinya lebih berpikir kritis, kreatif, dan inovatif, karena kompetensi inilah yang sangat diperlukan di dalam masyarakat 5.0, yaitu berusaha berinovasi dan memecahkan masalah yang dihadapi dalam kehidupan sehari-hari dengan menggabungkan daya kreativitas penggunaan media teknologi yang bisa membangun masyarakat yang lebih maju.

Namun di dalam pelaksanaannya, strategi ini memiliki kelemahan dan kelebihan yang harus diketahui oleh guru agar bisa meminimalisir kesalahan-kesalahan yang mungkin bisa saja terjadi. Adapun keunggulan dari strategi ini seperti yang dirumuskan oleh Nasution adalah: (1) strategi inkuiri merupakan strategi yang menekankan pada tiga ranah pembelajaran, yaitu kognitif, afektif, dan psikomotorik yang secara seimbang, sehingga proses pembelajaran lebih bermakna. (2) strategi inkuiri dapat membimbing peserta didik untuk belajar sesuai dengan gaya belajar mereka masing-masing. 3) strategi inkuiri merupakan strategi yang sesuai dengan perkembangan psikologi modern, dimana psikologi modern belajar adalah perubahan tingkah laku yang dipengaruhi oleh adanya pengalaman. 4) strategi inkuri dapat melayani peserta didik yang memiliki kemampuan belajar di atas rata-rata. Artinya peserta didik yang memiliki kemampuan belajar tinggi tidak akan terhambat oleh peserta didik yang memiliki kemampuan belajar rendah (Nasution, 2017).

\section{Strategi Discovery Learning}

Strategi discovery learning atau bisa juga dikatakan sebagai strategi penemuan merupakan strategi yang relevan untuk diterapkan di era society 5.0. Strategi discovery learning dapat diartikan sebagai strategi pembelajaran yang materinya tidak disampaikan secara langsung atau hanya disampaikan bagian tertentu saja, selebihnya siswa diarahkan untuk menemukan dan mengorganisasikan pemahamannya mengenai topik tersebut secara mandiri. Artinya, peserta didik dilatih untuk menjadi seorang saintis (ilmuan).(Royani, 2020) Sedangkan menurut Fauzi, dkk mengatakan bahwa strategi discovery learning merupakan model 
pembelajaran yang tidak menyampaikan keseluruhan materi. Materi disampaikan sebagian saja, sedangkan yang lainnya ditemukan sendiri oleh peserta didik (Fauzi et al., 2017). Oleh karena itu, strategi discovery learning menuntut peserta didik untuk lebih aktif menemukan bagian pengetahuan yang belum disampaikan.

Dalam penerapan strategi discovery learning, guru hendaknya sebisa mungkin untuk memotivasi dan membimbing peserta didik agar lebih aktif dalam belajar mandiri. Dalam mengaplikasikan strategi discovery learning guru berperan sebagai fasilitator dengan memberikan kesempatan kepada peserta didik untuk belajar lebih aktif, sehingga peserta didik bisa menjadi seorang problem solver, seorang saintis, dan seorang historian. Dengan demikian siswa dapat menemukan, menguasai, dan menerapkan hal-hal yang ditemukannya dalam proses pembelajaran di dalam kehidupan sehari-hari.

Strategi discovery learning dalam pembelajaran Pendidikan Agama Kristen sangat membantu peserta didik untuk menemukan pengetahuan dan pengalaman baru dalam proses pembelajaran. Strategi ini sangat tepat digunakan jika topik yang dibahas cukup luas, misalnya tentang sejarah kekristenan, sejarah perkembangan gereja dan sebagainya maka materi tidak sepenuhnya dijelaskan kepada peserta didik, akan tetapi peserta didik diberikan kebebasan untuk berekspresi dan menemukan sendiri pengetahuan baru yang belum disampaikan oleh guru, sehingga tidak hanya pengetahuan semata tetapi juga peserta didik memperoleh pengalaman yang berharga dalam proses pembelajaran.

Menurut Fauzi, ada langkah-langkah yang harus diperhatikan dalam menerapkan strategi discovery learning, antara lain: 1) stimulasi, 2) pernyataan masalah, 3) pengumpulan data, 4) pengolahan data, dan 5) verifikasi atau generalisasi (Fauzi et al., 2017). Langkah-langkah tersebut sudah menunjukkan langkah penelitian ilmiah, sehingga pembelajaran akan lebih terlihat sistematis dan analitis, dengan demikian memudahkan peserta didik untuk menemukan pengetahuan baru dan konsep yang baru serta bisa mengasah kemampuan peserta didik dalam mengkomunikasikannya kepada peserta didik lainnya.

Oleh karena itu, discovery learning sangat bisa digunakan dalam strategi pembelajaran di era society 5.0, dimana dengan adanya kesempatan luas bagi peserta didik untuk mencari pengetahuan itu sendiri, maka akan menumbuhkan daya inovasi peserta didik dalam memanfaatkan teknologi yang ada, artinya peserta didik dapat mengkombinasikan daya berpikirnya untuk menemukan konsep atau pengetahuan yang baru dengan media teknologi yang ada, sehingga tidak hanya berharap teknologi itu sendiri tetapi juga peran aktif dan daya pikirnya sangat dibutuhkan.

\section{Strategi Koorperatif}

Strategi pembelajaran koorperatif juga merupakan salah satu strategi yang dapat diterapkan dan dimanfaatkan di era society 5.0, dimana strategi ini lebih menekankan pada kerjasama dan interaksi sosial. Menurut Wati dan Anggraini strategi pembelajaran koorperatif adalah strategi pembelajaran yang membagi peserta didik dalam beberapa kelompok kecil yang saling bekerjasama dan memaksimalkan kondisi belajar untuk mencapai tujuan pembelajaran. Kelompok kecil ini beranggotakan 4-5 orang.(Wati \& Anggraini, 2019) Dengan demikian dapat dikatakan bahwa strategi pembelajaran kooperatif akan lebih menarik karena dalam proses pembelajaran peserta didik akan lebih banyak berintaraksi dengan peserta didik lainnya.

Sedangkan menurut Nasution, strategi pembelajaran koorperatif adalah strategi pembelajaran yang implementasinya mengarahkan peserta didik untuk bekerjasama dalam kelompok-kelompok kecil demi mencapai tujuan pembelajaran.(Nasution, 2017). Oleh karena itu, strategi pembelajaran koorperatif adalah strategi pembelajaran yang mengembangkan kemampuan siswa dalam berintaraksi dan bekerjasama antara satu dengan yang lain untuk bersama-sama mencapai tujuan pembelajaran. Adapun tujuan pembelajaran 
yang harus dicapai melalui strategi koorperatif adalah prestasi akademik, penerimaan keberagaman peserta didik, dan pengembangan keterampilan interaksi sosial.

Pendidikan Agama Kristen tidak hanya menekankan aspek kognitif dan psikomotorik, namun lebih menekankan aspek kognitif. Untuk melatih kematangan aspek afektif peserta didik, maka strategi kooperatif adalah strategi yang tepat untuk diterapkan. Dalam Gal. 6:2 dituliskan bahwa "Bertolongtolonglah menanggung bebanmu. Demikian lah kamu memenuhi hukum Kristus." Oleh karena itu, peserta didik sebagai makhluk sosial saling membutuhkan antara satu dengan yang lain. Demikian juga dalam proses pembelajaran, peserta didik dilatih untuk bekerjasama, toleransi, bertanggungjawab, dan memiliki sikap peduli terhadap lingkungan sekitar.(Gulo, 2020) Sehingga sikap individualis yang muncul akibat perkembangan teknologi yang semakin maju dapat diminimalisir dengan baik.

Namun, dalam menerapkan strategi pembelajaran koorperatif guru harus memahami terlebih dahulu ciri-ciri strategi tersebut. Adapun ciri-ciri strategi koorperatif seperti yang dirumuskan oleh Nasution adalah: Pertama, pembentukan kelompok dengan sistem heterogenitas. Artinya kelompok dibagi berdasarkan heterogen atau multikultural mulai dari jenis kelamin, kemampuan akademis, dan suku. Dalam mengembangkan konsep heterogenitas ada dua alasan yang mendasarinya, antara lain : a) pembelajaran koorperatif sebagian dikembangkan oleh kaum humanis. Pemikiran humanis lebih menekankan pada perkembangan pribadi dan sosial peserta didik, yang tujuan utamanya adalah membuat peserta didik merasa lebih baik terhadap dirinya sendiri dan dapat menerima kehadiran orang lain. b) setiap peserta didik selain dapat mengembangkan kemampuan akademiknya, juga dapat mengembangkan kemampuan akademik peserta didik yang lain yang memiliki kemampuan akademik rendah.

Selain itu, beberapa kajian juga mengungkapkan bahwa melalui kelompok heterogenitas dapat bermanfaat bagi peserta didik yang memiliki prestasi tinggi maupun peserta didik yang memiliki prestasi rendah. Artinya, peserta didik dengan prestasi yang tinggi dapat mempertajam pemahamannya tentang materi yang dijelaskannya dan peserta didik yang memiliki prestasi rendah dapat lebih mudah memahami penjelasan-penjelasan yang diberikan oleh peserta didik yang berprestasi tinggi.

Ciri kedua adalah tugas-tugas diberikan melalui kelompok bukan individu. Artinya dalam proses pembelajaran koorperatif lebih banyak menggunakan kerja kelompok sehingga peserta didik dapat saling berinteraksi dan aktif dalam proses pembelajaran. Ciri ketiga, adalah dalam strategi pembelajaran koorperatif dibutuhkan tanggungjawab individu. Peserta didik dituntut untuk memiliki tanggungjawab terhadap dirinya sendiri dan kelompoknya agar saling membantu dan memotivasi anggota kelompoknya dalam mencapai tujuan pembelajaran secara bersama-sama. Ciri keempat, adalah sistem penghargaan. Penghargaan diberikan kepada peserta didik maupun kelompok yang dapat mencapai tujuan pembelajaran. Hal ini dimaksudkan agar peserta didik lebih termotivasi untuk berkompetisi, dengan demikian peserta didik dapat menggunakan semua pontesinya dengan maksimal dan terlibat aktif dalam proses pembelajaran (Nasution, 2017).

Dengan demikian, dapat disimpulkan bahwa strategi pembelajaran koorperatif sangat memungkinkan untuk diterapkan di era society 5.0, dimana strategi ini dapat menstimulus peserta didik untuk berinteraksi dan bekerjasama, tidak hanya dalam dunia nyata tetapi juga dalam dunia virtual. Selain itu, strategi koorperatif juga dapat meningkatkan harga diri peserta didik, kesadaran sosial, dan toleransi antar peserta didik, yang dapat menumbuhkan rasa empati dan kerjasama serta meningkatkan prestasi akademik peserta didik. 


\section{Strategi Blended Learning}

Strategi blended learning bisa menjadi pilihan dalam proses pembelajaran di era society 5.0, dimana strategi ini menggabungkan gaya mengajar tradisional dengan gaya mengajar modern. Menurut Widiara, mengatakan bahwa strategi blended learning merupakan suatu sistem pembelajaran yang menggabungkan antara belajar face to face (tatap muka/klasikal) dengan belajar secara online (melalui fasilitas internet)(Widiara, 2018). Sedangkan menurut Saifuddin, mengatakan bahwa strategi blended learning dapat diartikan sebagai proses pembelajaran yang konvensional di kelas dikombinasikan dengan pembelajaran online baik secara mandiri maupun kolaborasi dengan menggunakan fasilitas teknologi informasi dan komunikasi.(Saifuddin, 2020) Jadi, pada dasarnya strategi blended learning adalah menggunakan dua sistem pembelajaran sekaligus, yaitu belajar secara tatap muka dan belajar secara online.

Dengan adanya kemajuan teknologi saat ini, belajar bukan hal yang sulit dilakukan karena dapat diakses dimana saja dan kapan saja, tidak dibatasi oleh ruang dan waktu. Begitu juga dalam Pendidikan Agama Kristen, hal ini bisa dilakukan kapan saja dan dimana saja. Yesus dalam mengajar murid-muridNya juga tidak dibatasi oleh ruang dan waktu. Yesus mengajar kapan saja dan dimana saja Ia mau. Yesus mengajar di atas bukit (Mat. 5), Yesus mengajar di atas perahu (Luk. 5:3), Yesus mengajar di rumah ibadat (4:23). Tentu dengan berbagai tempat yang digunakan oleh Yesus ketika mengajar memberikan pengalaman baru dan membuka daya imajinasi murid-murid-Nya sehingga mudah memahami isi pengajarannya.

Demikian pula dalam pembelajaran Pendidikan Agama Kristen saat ini, dimana guru dapat mengkombinasikan beberapa gaya mengajar, di dalam kelas secara tatap muka maupun dengan memanfaatkan media teknologi atau internet sebagai tempat mengajar. Tentu kombinasi kedua gaya mengajar ini memberikan pengalaman kepada peserta didik serta membuka imajinasi peserta didik dalam belajar sehingga peserta didik semakin kreatif, inovatif, dan kritis dalam proses pembelajaran. Selain itu, menurut hemat penulis dengan kombinasi kedua gaya mengajar ini, masalah yang ditemukan dalam pembelajaran tatap muka dapat dicari solusinya melalui pembelajaran berbasis teknologi, dan sebaliknya masalah yang ditemukan dalam pembelajaran berbasis teknologi dapat ditemukan solusinya melalui pembelajaran tatap muka.

Tujuan utama strategi blended learning adalah untuk memberikan kesempatan kepada peserta didik untuk belajar sesuai dengan karakteristiknya masing-masing sehingga bisa belajar secara mandiri, berkelanjutan, dan berkembang secara terus menerus. Hal ini bisa dilakukan dengan memanfaatkan dan mengkombinasikan berbagai media teknologi yang sudah ada.

Dengan demikian dapat disimpulkan bahwa strategi pembelajaran blended learning merupakan strategi yang relevan digunakan di era society 5.0, karena strategi tersebut menggunakan kombinasi pembelajaran tatap muka dan pembelajaran secara online, artinya selain terjadinya interaksi sosial dalam pembelajaran tatap muka, juga guru dan peserta didik dapat berinteraksi melalui media teknologi sehingga adanya keseimbangan penggunakan media teknologi. Artinya bila siswa mengalami kesulitan dalam belajar secara tatap muka maka bisa memilih secara online atau sebaliknya.

Penelitian ini hendaknya menawarkan bahwa strategi pembelajaran Pendidikan Agama Kristen mengikuti berbagai perubahan zaman khusunya di era society 5.0. Poin-poin kajian dalam artikel masih relevasi untuk diterapkan. Artinya bahwa strategi Pendidikan Agama Kristen tidak lagi bergantung penuh pada perspektif pendidikan sekuler. Dan kajian ini belum dibahas secara spesifik di penelitian-penelitian sebelumnya.. 


\section{Kesimpulan}

Berdasarkan kajian penelitian yang sudah dijelaskan di atas, maka penulis menyimpulkan bahwa strategi pembelajaran sangat penting dalam kegiatan belajar mengajar, hal ini bertujuan untuk memudahkan siswa dalam memahami materi ajar. Ditambah lagi dengan kehadiran teknologi atau era society 5.0 yang membawa perubahan dalam dunia pendidikan. Guru diharuskan untuk berinovasi dan mengembangkan strategi pembelajaran yang sesuai dengan perkembangan teknologi di era society 5.0, supaya teknologi yang ada dapat digunakan untuk memecahkan masalah sosial yang terjadi dalam masyarakat. Kehadiran era society 5.0 dalam pendidikan juga harus dimanfaatkan dengan baik, agar siswa dapat berpikir lebih kritis, konstruktif, dan inovatif serta bisa bersaing dalam membangun masyarakat dan negara yang lebih maju dan berkarakter, untuk mencapai tujuan tersebut guru harus mempersiapkan strategi pembelajaran yang relevan di era society 5.0, dalam kegiatan pembelajaran, khususnya dalam pembelajaran Pendidikan Agama Kristen. Adapun strategi pembelajaran yang relevan dalam Pendidikan Agama Kristen di era society 5.0 adalah strategi partisipatif, strategi inkuiri, strategi discovery learning, strategi kooperatif, dan strategi blanded learning.

\section{Referensi}

Ariefin, D., \& Darmawan, I. P. A. (2021). Pemecahan Masalah dalam Pembelajaran Melalui Kreativitas Guru Selama Masa Pandemi. PASCA : Jurnal Teologi Dan Pendidikan Agama Kristen, 17(1), 5563.

Arjunaita. (2020). Pendidikan di Era Revolusi Industri 5.0. Prosiding Seminar Nasional Pendidikan Program Pascasarjana Universitas Pgri Palembang, 179-196.

Asrori, M. (2013). Pengertian, Tujuan dan Ruang Lingkup Strategi Pembelajaran. Jurnal MANDRASAH, 5(2), 163-188.

Diana, R. (2019). Prinsip Teologi Kristen Pendidikan Orang tua terhadap Anak di Era Revolusi Industri 4.0. Jurnal BIA : Teologi Dan Pendidikan Kristen Kontekstual, 2(1), 27-39.

Dwijora, N. V., \& Simanjuntak, J. (2020). Model Pembelajaran Berbasis Inkuiri dalam Mata Pelajaran Pendidikan Agama Kristen. TEDC, 14(3), 249-254.

Fauzi, A. R., Zainuddin, Z., \& Atok, R. Al. (2017). Penguatan Karakter Rasa Ingin Tahu dan Peduli Sosial melalui Discovery Learning. Jurnal Teori Dan Praksis Pembelajaran IPS, 2(2), 79-88. https://doi.org/10.17977/um022v2i22017p079

Gulo, F. (2020). Tinjauan Teologis Model Pembelajaran Kooperatif Tipe TGT. Giligentia:Journal of Theology and Christian Education, 2(2), 31-50.

H. Mulyono, \& Wekke, I. S. (2018). Strategi Pembelajaran di Abad Digital. In Gawe Buku. Gawe Buku. Handayani, N. N. L., \& Muliastrini, N. K. E. (2020). Pembelajaran Era Disruptif Menuju Era Society 5.0 (Telaah Perspektif Pendidikan Dasar) Ni. International Seminar Proceeding, 3(2252), 58-66.

Ipiana, Novitasari, K. D., \& Mononimbar, Y. Y. (2021). Internalisasi Pendidikan Karakter Melalui Pendidikan Agama Kristen. Jurnal Metanoia:PENDIDIKAN AGAMA KRISTEN, 3(2), 75-97.

Keles, M. C. (2020). Strategi Pembelajaran Guru PAK di era Pandemi Covid-19 dalam Upaya Meningkatkan Motivasi Belajar Peserta Didik di Sekolah Menengah Atas Wilayah Kawangkoan. EJurnal Pendidikan Dan Teologi Kristen, 1(2), 94-112.

Kurniawan, N. A., \& Aiman, U. (2020). Paradigma Pendidikan Inklusi Era Society 5.0. Jurnal Pendidikan Dasar, 1-6. 
Mulyono, \& Wekke, I. S. (2018). Strategi Pembelajaran di Abad Digital. Africa's Potential for the Ecological Intensification of Agriculture, 1-204.

Muslim, A. (2017). Implementasi Pembelajaran Partisipatif Melalui Focus Group Discussion Dalam Meningkatkan Kemampuan Komunikasi Mahasiswa. Jurnal Paedagogy, Vol. 4(1), 15-20.

Nastiti, F. E., \& 'Abdu, A. R. N. (2020). Kesiapan Pendidikan Indonesia Menghadapi era society 5.0. Jurnal Kajian Teknologi Pendidikan, 5(1), 61-66.

Nasution, W. N. (2017). Strategi Pembelajaran. Perdana Publishing.

Puspita, Y., Fitriani, Y., Astuti, S., \& Novianti, S. (2020). Selamat Tinggal Revolusi Industri 4.0, Selamat

Datang Revolusi Industri 5.0. Prosiding Seminar Nasional Pendidikan Program Pascasarjana Universitas Pgri Palembang, 122-130.

Royani, I. (2020). Peningkatan Kompetensi Guru Menuju Industri 5.0. Prosiding Seminar Nasional Pendidikan Program Pascasarjana Universitas PGRI Palembang, 449-456.

Saifuddin. (2020). Peningkatan Kapabilitas Problem Solving Dengan Strategi Blended Learning: Membelajarkan Siswa Di Era Disruptif. Jurnal AL-WIJDÁN, 5(2), 123-137.

Setiawan, A. A. J. (2018). Metodologi Penelitian Kualitatif. CV Jejak.

Setiawan, D., \& Lenawati, M. (2020). Peran Dan Strategi Perguruan Tinggi Dalam Menghadapi Era Society 5.0. Journal of Computer, Information System, \& Technology Management, Vol. 3(No. 1), 1-7.

Simamora, K. S. D. (2019). Pendidikan Agama Kristen dan Signifikansinya dalam Pembentukan Karakter. Jurnal Providensi:Pendidikan Dan Teologi, 2(2), 36-53.

Sururuddin, M., \& Dkk. (2021). Strategi Pendidik Dengan Media Pembelajaran Berbasis Multimedia Untuk Menghadapi Era Society 5.0. Jurnal DIDIKA : Wahana Ilmiah Pendidikan Dasar, 7(1), 143-148.

Wati, M., \& Anggraini, W. (2019). Strategi Pembelajaran Koperatif Tipe Jigsaw: Pengaruhnya Terhadap Kemampuan Berpikir Kritis. Journal of Science and Mathematics Education, Vol. 2(1), 98-106.

Widiara, I. K. (2018). Blended Learning Sebagai Alternatif Pembelajaran di Era Digital. Jurnal Purwadita, Vol. 2(2), 50-56.

Zaluchu, S. E. (2020). Strategi Penelitian Kualitatif dan Kuantitatif Di Dalam Penelitian Agama. Evangelikal: Jurnal Teologi Injili Dan Pembinaan Warga Jemaat, 4(1), $28-38$. https://doi.org/10.46445/ejti.v4i1.167

Zaluchu, S. E. (2021). Metode Penelitian di dalam Manuskrip Jurnal Ilmiah Keagamaan. Jurnal Teologi Berita Hidup, 3(2), 249-266. 